\title{
PENGARUH PENEMPATAN DISTRIBUTED GENERATION (DG) TERHADAP KEANDALAN PENYULANG MRA05 GI MRICA BANJARNEGARA
}

\author{
Bambang Winardi' ${ }^{1)}$, Tedjo Sukmadi ${ }^{2}$, Enda Wista Sinuraya ${ }^{3)}$, Agung Nugroho ${ }^{4}$ \\ Departemen Teknik Elektro \\ ${ }^{1,2,3,4)}$ Universitas Diponegoro Semarang \\ Jl. Prof. Sudharto, SH, Semarang 50275, Indonesia \\ Email : bbwinar@gmail.com
}

\begin{abstract}
Abstrak
Tenaga listrik merupakan kebutuhan pokok bagi masyarakat, sehingga kontinuitas penyediaan tenaga listrik menjadi tuntutan yang semakin besar dari konsumen. Penyulang MRA05 GI Mrica Banjarnegara menyuplai energi listrikuntuk sebagian wilayah Kecamatan Rakit Kabupaten Banjarnegara sampai tahun2017 memiliki 4 Distritributed Generation (DG), yaitu PLTMH Sigebang 500 KW, PLTMH Kincang 320 KW, PLTMH Adipasir 320 KW, PLTMH Rakit 500 KW.Berdasarkan data catatan pada tahun 2017 Penyulang MRA05 mengalami pemadaman sebanyak 15 kali/tahun, dengan total lama padam 38,68 jam/tahun, hal ini tentunya cukup mengganggu kontinuitas penyaluran energi listrik ke konsumen. Berdasarkan permasalah tersebut maka perlu adanya studi tentang perhitungan tingkat keandalan sistem tenaga listrik pada penyulang MRA05.Pada penelitian ini dibahas besarnya indeks keandalan (SAIFI, SAIDI, CAIDI) pada saat kondisi DG tidak terpasang dan terpasang. Perhitungan besarnya indeks keandalan dilakukan dengan menggunakan metode Reliability Index Assesment (RIA), hasil perhitungan dibandingkan dengan hasil simulasi software ETAP 12.6.0. Indeks keandalan berdasarkan metode RIA saat DG tidak terpasang, dan nilai SAIFI adalah 2,96228 gangguan/tahun, besar SAIDI adalah 9,1185 jam/tahun, nilai CAIDI sebesar 3,078 jam/gangguan, Saat DG terpasang, besar SAIFI adalah 2,96228 gangguan/tahun, besar SAIDI adalah 7,567 jam/tahun, besarnya CAIDI adalah 2,5546 jam/gangguan.
\end{abstract}

Kata Kunci: Distributed Generation (DG), ETAP 12.6.0, index keandalan.

\section{PENDAHULUAN}

Penyulang MRA05 GI Mrica Banjarnegara menyuplai energi listrik untuk di wilayah Kecamatan Rakit Banjarnegara, pada tahun 2018 mengalami pemadaman sebanyak $15 \mathrm{kali}$, dengan total lama padam 38,68 jam. Sampai dengan tahun 2018pada Penyulang MRA05 memiliki 4 unitDistributed Generation (DG) jenis Pembangkit Listrik Tenaga Mikrohidro (PTMH), yaitu PLTMH Sigebang 500 KW, PLTMH Kincang 320 KW, PLTMH Adipasir 320 KW, PLTMH Rakit 500 KW.

DG diartikan suatu pembangkit dengan kapasitas maksimal berkisar sampai $50 \mathrm{MW}$ dan disalurkan pada jaringan distribusi[1]. Salah satu keuntungan dengan adanya DG pada sistem jaringan distribusi adalah dapat membantu meningkatkan keandalan pada jaringan distribusi[2]. Keandalan jaringan distribusi dapat dilihat pada besar kecilnya indeks keandalan pada jaringan tersebut[3].

Salah satu metode untuk menghitung besarnya indeks keandalan pada jaringan distribusi dapat menggunakan metode Reliability Index Assesment (RIA). Secara fungsional metode RIA akan mendata kegagalan yang terjadi pada peralatan secara komperehensif, lalu mengidendifikasi kegagalan tersebut, dan menganalisis mode kegagalan tersebut, sehingga akan dihasilkan indeks-indeks keandalan pada jaringan distribusi tersebut[4].

Berdasarkan latar belakang tersebut, maka penulis mencoba melakukan penelitian ini bertujuan untuk mengetahui pengaruh DG terhadap indeks keandalan pada penyulang MRA05 dengan menggunakan metode RIA dan simulasi menggunakan software ETAP 12.6.0

\section{LANDASAN TEORI}

\subsection{Distributed Generation (DG)}

DG adalah pembangkit terdistribusi sebagai semua unit pembangkit dengan kapasitas maksimal berkisar sampai 50 MW dan dipasangkan ke jaringan distribusi. Berdasarkan definisi di atas menunjukkan bahwa pembangkitan dengan skala kecil yang dihubungkan ke jaringan distribusi baik dipasangkan 
dekat dengan beban atau konsumen dapat dikatakan sebagai Distributed Generation (DG).

Dalam penyambungannya, DG biasanya ditempatkan di titik ujung beban[17]. Berikut merupakan salah satu contoh pemasangan pembangkit terdistribusi jika disambungkan dengan sistem distribusi tenaga listrik radial yang dapat dilihat pada Gambar 1 .

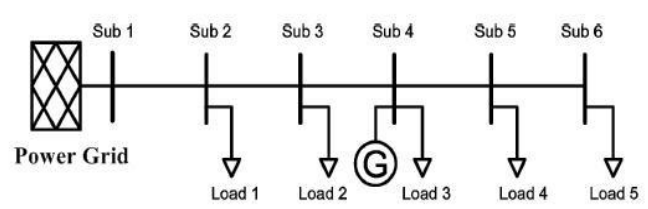

Gambar 1.Sistem distribusi dengan pembangkit terdistribusi didalamnya [18].

\subsection{Keandalan}

Keandalan adalah merupakan nilai keberhasilan suatu kinerja sebuah sistem tenaga listrik agar dapat mendapatkan hasil yang lebih baik pada jangka waktu dan pada kondisi tertentu[9]. Untuk mendapatkan tingkat keandalan pada suatu sistem, diperlukan pemeriksaan dan perhitungan kemudian dilakukan analisa terhadap nilai keberhasilan kinerja dan operasi pada suatu sistem ditinjau pada periodeperiode tertentu, kemudian dilakukan perbandingan dengan nilai standar yang ditetapkan sebelumnya. Tingkat keberhasilan pada kinerja operasi sistem mempengaruhi kualitas penyaluran energi listrik pada konsumen.

\subsection{Reliability Index Assesment (RIA)}

Metode RIA adalah sebuah pendekatan yang digunakan untuk memprediksi gangguan pada sistem distribusi berdasarkan topologi sistem dan data-data mengenai component reliability

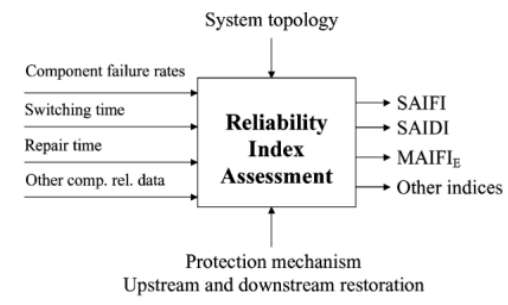

Gambar 2.Input dan Output dari RIA [13]

Seacara fungsional, RIA mendata kegagalan yang terjadi pada peralatan secara komprehensif, lalu mengidentifikasi kegagalan tersebut, dan menganalisis mode kegagalan tersebut. [4]

\subsubsection{Indeks Keandalan}

Indeks keandalan pada sistem merupakan suatu cara atau metode untuk evaluasi terhadap parameter-parameter keandalan untuk peralatan pada distribusi tenaga listrik terhadap nilai tingkat mutu pelayanan pada pelanggan[14]. Indeks keandalan dapat dilihat dari dua sisi, yaitu dari sisi konsumen (consumer-based) atau dari sisi beban (load-based).

a) Indeks Keandalan Berdasarkan Konsumen

Kontinuitas penyaluran energi listrik kepada konsumen menjadi parameter utama indeks keandalan ini. Frekuensi dan lamanya pemadaman yang dialami oleh konsumen serta jumlah konsumen yang dilayani menentukan nilai dari indeks keandalan berdasarkan pelanggan. Berikut adalah tiga indeks keandalan berdasarkan konsumen, yaitu SAIFI (System Average Interruption Frequency Index),S AIDI (System Average Interruption Duration Index) dan CAIDI (Customer Average Interruptions Durations Index)[2].

\section{- System Average Interruption Frequency Index (SAIFI)}

besarnya Indeks memberikan gambaran tentang frekuensi rata-rata pemadaman yang dialami konsumen dalam kurun waktu satu tahun. Indeks ini dirumuskan sebagai berikut[2].

$$
\begin{aligned}
\text { SAIFI }= & \frac{\text { totalnumberofcustomerinterruptions }}{\text { totalnumberofcustomerserved }} \\
& =\frac{\sum \lambda i \cdot N i}{\sum N i}
\end{aligned}
$$

Dimana:

$\lambda_{i}=$ laju kegagalan

$N_{i}=$ jumlah pelanggan pada titik beban $i$

\section{- System Average Interruption Duration Index (SAIDI)}

Indeks ini menggambarkan durasi atau lama pemadaman rata-rata yang dialami oleh pelanggan dalam kurun waktu satu tahun. Indeks ini dirumuskan sebagai berikut[2].

$$
\begin{aligned}
& \text { SAIDI } \\
& =\frac{\text { SumofCustomerInterruptiondurations }}{\text { Totalnumberofcustomerserved }} \\
& =\frac{\sum U i \cdot N i}{\sum N i}
\end{aligned}
$$

Dimana:

$U_{i}=$ durasi pemadaman tahunan untuk beban $i$ $N_{i}=$ jumlah pelanggan pada titik beban $i$

\section{- Customer Average Interruption Duration Index (CAIDI)}


Indeks ini memberikan informasi lama waktu (durasi) rata-rata setiap pemadaman Indeks ini dirumuskan dengan[2]:

\section{CAIDI}

$$
\begin{gathered}
=\frac{\text { sumofcustomerinterruptiondurations }}{\text { totalnumberofcustomerinterruption }} \\
=\frac{\sum U i . N i}{\sum_{\lambda A i . N i}} \\
=\frac{S A I D I}{S A I F I}
\end{gathered}
$$

\section{b) Indeks Keandalan Berdasarkan Beban}

Salah satu parameter penting dalam evaluasi indeks keandalan berdasarkan beban adalah rata-rata beban pada setiap titik beban. Berikut ada dua indeks keandalan berdasarkan beban, yaitu ENS (Energy Not Supplied) dan AENS (Average Energy Not Supplied)[2].

\section{- Energy Not Supplied (ENS)}

Indeks ini memberikan informasi tentang total energi yang tidak terkirim dalam satu tahun.

Dimana:

$$
E N S=\sum L a(i) . U i
$$

$\mathrm{La}(\mathrm{i})=$ rata-rata beban yang terhubung pada titik beban i

Ui = durasi pemadaman tahunan pada titik beban $\mathrm{i}$

\section{- Average Energy Not Supplied (AENS)}

$$
\begin{gathered}
A E N S=\frac{\text { totalenergynotsupplied }}{\text { totalnumbercustomersserved }} \\
=\frac{\sum L a(i) \cdot U i}{\sum N i}
\end{gathered}
$$

Dimana:

$\mathrm{La}(\mathrm{i})=$ rata-rata beban yang terhubung pada titik beban $\mathrm{i}$

$\mathrm{Ui}=$ durasi pemadaman tahunan pada titik beban i

$\mathrm{Ni}=$ jumlah pelanggan pada titik beban $\mathrm{i}$

\section{METODOLOGI PENELITIAN}

\subsection{Langkah Penelitian}

Pada penelitian ini bertujuan untuk mengetahui besarnya indeks keandalan pada penyulang MRA05 saat kondisi DG tidak terpasang dan terpasang dengan menggunakan metode RIA dan simulasi ETAP. Langkah-langkah penelitian ini sebagai berikut:

\section{a. Pengumpulan Data}

Data-data pada penelitian ini diperoleh dari PT. PLN (Persero) Rayon Banjarnegara antara lain single line diagram, data trafo distribusi,data pemadaman pada tahun 2017dan data pelengkap lainnya. Selain itu terdapat juga data hasil literatur laju kegagalan komponen, dan impedansi penghantar.

\begin{tabular}{|c|c|c|c|c|}
\hline \multirow{3}{*}{$\begin{array}{l}\text { Diamete } \\
\mathbf{r}\left(\mathbf{m m}^{2}\right)\end{array}$} & \multicolumn{4}{|c|}{$\mathbf{A A \mathbf { A } C}$} \\
\hline & \multicolumn{2}{|c|}{$\mathrm{Z1}, \mathrm{Z2}(\Omega / \mathbf{k m})$} & \multicolumn{2}{|c|}{$\mathrm{Z0}(\Omega / \mathbf{k m})$} \\
\hline & $\mathbf{R}$ & $\mathbf{j} \mathbf{X}$ & $\mathbf{R}$ & $\mathbf{j} \mathbf{X}$ \\
\hline 16 & 2,0161 & 0,4036 & 2,1641 & 1,6911 \\
\hline 25 & 1,2903 & 0,3895 & 1,4384 & 1,6770 \\
\hline 35 & 0,9217 & 0,3790 & 1,0697 & 1,6665 \\
\hline 50 & 0,6452 & 0,3678 & 0,7932 & 1,6553 \\
\hline 70 & 0,4608 & 0,3572 & 0,6088 & 1,6447 \\
\hline 95 & 0,3096 & 0,3449 & 0,4876 & 1,6324 \\
\hline 120 & 0,2688 & 0,3376 & 0,4168 & 1,6250 \\
\hline 150 & 0,2162 & 0,3305 & 0,3631 & 1,6180 \\
\hline 185 & 0,1744 & 0,3239 & 0,3224 & 1,6114 \\
\hline 240 & 0,1344 & 0,3158 & 0,2824 & 1,6032 \\
\hline
\end{tabular}

Tabel 1. Laju kegagalan komponen sistem distribusi[5]

\begin{tabular}{|l|l|c|}
\hline \multicolumn{1}{|c|}{ Komponen } & Laju Kegagalan & $\begin{array}{c}\text { Repair Time } \\
\text { (jam) }\end{array}$ \\
\hline SUTM & 0,2/km/tahun & 3 \\
SKTM & 0,07/km/tahun & 10 \\
Pemutus tenaga $(P M T)$ & 0,004/unit/tahun & 10 \\
Sakelar beban & 0,003/unit/tahun & 10 \\
Sakelar pisah & 0,003/unit/tahun & 10 \\
Penutup balik & 0,005/unit/tahun & 0,25 \\
Penyambung kabel & 0,001/unit/tahun & 15 \\
Trafo distribusi & 0,005/unit/tahun & 10 \\
Pelindung jaringan & 0,005/unit/tahun & 0,25 \\
Rel tegangan rendah & 0,001/unit/tahun & 10 \\
(spot network) & \\
\hline
\end{tabular}

Tabel 2. Trafo distribusi penyulang MRA05

\begin{tabular}{|c|cc|c|}
\hline No & $\begin{array}{c}\text { Titik } \\
\text { Beban }\end{array}$ & Lokasi & $\begin{array}{r}\text { Kapasitas } \\
\text { (kVA) }\end{array}$ \\
\hline 1 & load1 & sigebang & 50 \\
2 & load2 & sigebang & 50 \\
3 & tapen & 50 \\
4 & load3 & lengkong & 50 \\
5 & load5 & lengkong & 50 \\
6 & load6 & lengkong & 25 \\
7 & load7 & lengkong & 25 \\
8 & load8 & lengkong & 50 \\
9 & load9 & lengkong & 50 \\
10 & load10 & lengkong & 25 \\
11 & load11 & badamita & 50 \\
12 & load12 & badamita & 25 \\
13 & load13 & lengkong & 630 \\
14 & load14 & badamita & 25 \\
15 & load15 & badamita & 50 \\
16 & load16 & badamita & 25 \\
$\ldots$ & $\ldots \ldots \ldots$ & $\ldots \ldots \ldots .$. & $\ldots$. \\
143 & load143 & pingit & 25 \\
144 & load144 & pingit & 50 \\
145 & load145 & rakit & 25 \\
\hline \multicolumn{2}{r}{ TOTAL } & & $\mathbf{6 1 8 0}$ \\
\hline
\end{tabular}

Tabel 3. Impedansi penghantar

Tabel 4. Data panjang saluran pada penyulang MRA05

\begin{tabular}{|c|c|c|}
\hline No & Komponen & $\begin{array}{c}\text { Panjang } \\
\text { penghatar }(\mathbf{k m})\end{array}$ \\
\hline 1 & Line 1 & 0,25 \\
\hline
\end{tabular}

Seminar Nasional TEKNOKA ke - 4, Vol. 4, 2019 ISSN No. 2502-8782 


\begin{tabular}{|c|l|l|}
2 & Line 2 & 2,2 \\
3 & Line 3 & 0,15 \\
4 & Line 3.1 & 0,35 \\
5 & Line 3.2 & 0,6 \\
6 & Line 4 & 0,15 \\
7 & Line 5 & 0,3 \\
8 & Line 6 & 0,45 \\
9 & Line 6.1 & 0,35 \\
10 & Line 7 & 0,6 \\
$\ldots .$. & $\ldots \ldots .$. & $\ldots \ldots .$. \\
$\ldots .$. & $\ldots \ldots .$. & $\ldots \ldots$. \\
199 & Line 60.3 & 0,05 \\
200 & Line Sigebang & 0,1 \\
201 & Line Kincang & 0,35 \\
202 & Line Adipasir & 0,35 \\
203 & Line Rakit & 0,35 \\
\hline & TOTAL & $\mathbf{8 7 , 5 6 3}$ \\
\hline
\end{tabular}

Tabel 5. Data pembebanan penyulangMRA05

\begin{tabular}{|l|c|c|c|}
\hline $\begin{array}{l}\text { Gardu } \\
\text { Induk }\end{array}$ & Penyulang & $\begin{array}{c}\text { Rating } \\
\text { Arus (A) }\end{array}$ & $\begin{array}{c}\text { Arus Beban } \\
\text { (A) }\end{array}$ \\
\hline Mrica & MRA05 & 400 & 175 \\
\hline
\end{tabular}

Dari Tabel 5 dapat digunakan untuk menentukan besarnya pembeban yang digunakan pada simulasi dengan perhitungan sebagai berikut.

$$
\begin{aligned}
& \frac{\sqrt{3} V I_{\text {beban }}}{S_{\text {total trafo distribusi }}} \times 100 \% \\
& \% \text { trafo }=\frac{\sqrt{3 \times} \times 20 \mathrm{kV} \times 175 \mathrm{~A}}{6180 \mathrm{kVA}} \times 100 \% \\
& \% \text { trafo }=\frac{6062}{6180} \times 100 \% \\
& \% \text { trafo }=98 \%
\end{aligned}
$$

\begin{tabular}{|c|c|c|c|}
\hline No & Tanggal & $\begin{array}{c}\text { Lama Padam } \\
\text { (jam) }\end{array}$ & $\begin{array}{c}\text { Pelanggan } \\
\text { padam }\end{array}$ \\
\hline 1 & 11 januari 2017 & 5,28 & 11764 \\
\hline 2 & 13 januari 2017 & 3,23 & 11764 \\
\hline 3 & 04 februari 2017 & 2,25 & 11764 \\
\hline 4 & 01 maret 2017 & 3,58 & 11764 \\
\hline 5 & 10 maret 2017 & 3,23 & 11764 \\
\hline 6 & 01 april 2017 & 4,17 & 11764 \\
\hline 7 & 16 april 2017 & 0,65 & 11764 \\
\hline 8 & 11 juli 2017 & 1,47 & 11764 \\
\hline 9 & 15 juli 2017 & 2,53 & 11764 \\
\hline 10 & 26 juli 2017 & 1,63 & 11764 \\
\hline 11 & 05 september 2017 & 0,80 & 11764 \\
\hline 12 & 19 oktober 2017 & 3,67 & 11764 \\
\hline 13 & 25 oktober 2017 & 1,25 & 11764 \\
\hline 14 & 19 novemebr 2017 & 1,10 & 11764 \\
\hline 15 & 26 desember 2017 & 3,38 & 11764 \\
\hline \multicolumn{2}{|r|}{ TOTAL } & 38,68 & \\
\hline
\end{tabular}

Sehingga pada simulasi besar beban yang digunakan adalah $98 \%$ dari kapasitas tiap trafo distribusi.

Tabel 6. Data pemadaman pada penyulang MRA05
Pada tabel 6 diatas, penyebab terjadinya pemadaman sebagian besar disebakan oleh faktor non teknis seperti faktor lingkungan, alam dan faktor non teknis lainnya yaitu sebesar 73,33\%, sedangkan $26,67 \%$ disebkan oleh kegagalan komponen

\section{b. Penggambaran Pada ETAP 12.6.0}

Jaringan penyulang MRA05 digambar di ETAP 12.6.0 seperti ditunjukkan pada Gambar 3.

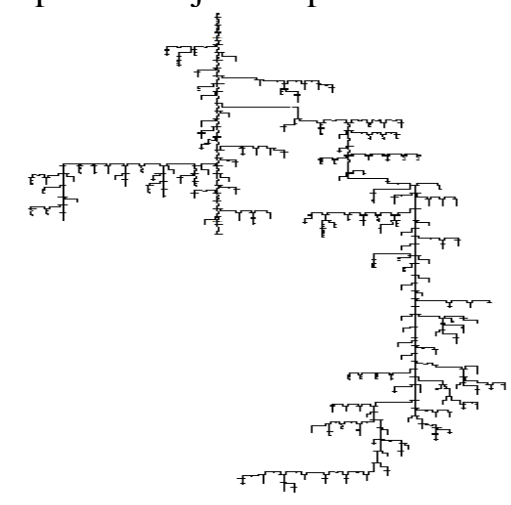

Gambar 3.PenggambaranMRA05 pada ETAP 12.6.0

\subsection{Simulasi dengan ETAP}

Simulasi digunakan untuk menentukan besarnya indeks keandalan menggunakan menu "Reliability Assessment" dengan hasil keluaran pada Reliability Assessmennt Report adalah indeks SAIFI, SAIDI, CAIDI, ENS. dan AENS.

\section{HASIL DAN PEMBAHASAN}

\subsection{Saat kondisi DG tidak Terpasang}

Pada kondisi ini diasumsikan ketika terjadi gangguan pada penyulang, maka PMT akan trip , sehingga suplai beban dari substation atau gardu induk ke semua titik beban menjadi putus, maka semua titik beban akan padam.

\subsubsection{Perhitungan menggunakan Metode RIA}

Indeks keandalan yang akan dihitung menggunakan metode reliability index assesment (RIA) yaitu SAIFI, SAIDI,CAIDI, ENS,AENS pada penyulang MRA05.

Langkah pertama untuk perhitungan indeks keandalan di simulasi ETAP dengan cara menghitung laju kegagalan titik beban $\left(\lambda_{\mathrm{i}}\right)$ baru kemudian kemudian menghitung lama gangguan dalam 1 tahun pada titik-titik beban $\left(\mathrm{U}_{\mathrm{i}}\right)$. Perhitungan laju kegagalan dan lama gangguan tahunan pada salah satu titik beban yaitu Bus3.

- Laju Kegagalan Bus 3 
Laju kegagalan pada bus 3 dipengaruhi oleh laju kegagalan bus 2, serta laju kegagalan komponen yang menuju bus 3, komponen yang menuju bus 3 adalah 0,25 SUTM dan 1 ABSW. Sehingga laju kegagalan bus 3 didapatkan sebagai berikut.

$\lambda_{L P}=\sum_{i=K} \lambda \mathrm{i}$

$\lambda_{3}=\lambda_{2}+0,25 x \lambda_{S U T M}+\lambda_{A B S W}$

$\lambda_{2}=0+0,25 \times 0,2+0,003$

$\lambda_{2}=0,053$ gangguan $/$ tahun

- Lama Gangguan Tahunan Bus 3

Lama gangguan di bus 3 dipengaruhi lama gangguan pada bus 2, serta lama gangguan komponen yang menuju bus 3, komponen yang menuju bus 3 adalah 0,25 SUTM dan 1 ABSW. Sehingga lama gangguan bus 3 dapat dihitung sebagai berikut.

$\mathrm{U}_{\mathrm{i}}=\sum_{i=K} \lambda_{i} x r_{j}$

$\mathrm{U}_{3}=U_{2}+\lambda_{P m t 1} x M T T R_{p m t 1}+$

$0,25 \times \lambda_{\text {SUTM }} \times M T T R_{S U T M}+\lambda_{A B S W} \times M T T R_{A B S W}$

$\mathrm{U}_{3}=0+(0,25 \times 0,2 \times 3)+(0,003 \times 10)$

$\mathrm{U}_{3}=0,18 \mathrm{jam} /$ tahun

Hasil dari perhitungan laju kegagalan dan lama gangguan tiap tahun dari seluruh titik beban ditunjukkan pada dalam Tabel 7.

Tabel 7. Rekapitulasi laju kegagalan dan lama gangguan tahunan seluruh titik beban

\begin{tabular}{|c|c|c|c|c|c|}
\hline No. & $\begin{array}{c}\text { Titik } \\
\text { Beban }\end{array}$ & $\lambda_{\mathrm{i}}(\mathbf{f} /$ year $)$ & $\mathbf{U}_{\mathrm{i}}(\mathbf{h} /$ year $)$ & $\mathbf{L}_{\mathbf{i}}(\mathbf{K W})$ & $\mathbf{N}$ \\
\hline 1 & Bus 1 & 0 & 0 & 0 & 0 \\
\hline 2 & Bus 2 & 0 & 0 & 0 & 0 \\
\hline 3 & Bus 3 & 0,053 & 0,18 & 0 & 0 \\
\hline 4 & Bus 4 & 0,493 & 1,5 & 0 & 0 \\
\hline 5 & Bus 5 & 0,523 & 1,59 & 0 & 0 \\
\hline 6 & Load-1 & 0,602 & 1,89 & 41,65 & 65 \\
\hline 7 & Load-2 & 0,722 & 2,25 & 41,65 & 47 \\
\hline 8 & Load-3 & 0,562 & 1,77 & 41,65 & 65 \\
\hline 9 & Load-4 & 0,785 & 2,46 & 41,65 & 141 \\
\hline 10 & Load-5 & 0,915 & 2,85 & 41,65 & 120 \\
\hline$\ldots$. & $\ldots .$. & $\ldots .$. & $\ldots .$. & $\ldots$ & $\ldots$. \\
\hline$\ldots$. & $\ldots \ldots$ & $\ldots .$. & $\ldots .$. & $\ldots$ & ...... \\
\hline 149 & Load-143 & 4,9446 & 15,00 & 20,825 & 65 \\
\hline 150 & Load-144 & 4,9546 & 15,03 & 41,65 & 65 \\
\hline \multicolumn{5}{|c|}{ TOTAL } & 11764 \\
\hline
\end{tabular}

Setelah nilai laju kegagalan, lama gangguan tahunan, Daya di titik beban $\left(\mathrm{L}_{\mathrm{i}}\right)$ jumlah pelanggan $(\mathrm{N})$ setiap titik beban diketahui, maka seterusnya dapat dihitung indeks SAIFI, SAIDI, CAIDI, ENS dan AENS.

a. System Average Interruption Frequency Index (SAIFI)

SAIFI $=\frac{\sum \lambda_{\mathrm{i}} \mathrm{N}_{\mathrm{i}}}{\mathrm{N}_{\mathrm{i}}}$

SAIFI $=\frac{\sum((0 x 0)+(0 x 0)+\cdots+4,9546)}{11764}$

SAIFI $=2,96228$ gangguan $/$ tahun b. System Average Interruption Duration Index (SAIDI)

SAIDI $=\frac{\sum \mathrm{U}_{\mathrm{i}} \mathrm{N}_{\mathrm{i}}}{\mathrm{N}_{\mathrm{i}}}$

SAIDI $=\frac{\sum((0 x 0)+(0 \times 0)+\cdots+(15,03 \times 65))}{11764}$

SAIDI $=9,1185 \mathrm{jam} /$ tahun

c. Customer Average Interruption Durtion index (CAIDI)

$$
\begin{aligned}
\text { CAIDI } & =\frac{\text { SAIDI }}{\text { SAIFI }}=\frac{9,1185}{2,96228} \\
& =3,078 \text { jam/gangguan }
\end{aligned}
$$

d. Energy Not Supplied (ENS)

$$
\begin{aligned}
& \mathrm{ENS}=\sum L a(i) \cdot U i \\
& \mathrm{ENS}=\sum 41,65 \times 1,89+41,65 \times 18,11562,25+\cdots+ \\
& 20,825 \times 15+41,65 \times 15,03
\end{aligned}
$$

ENS $=42,1842 \mathrm{MWh} / \mathrm{tahun}$

e. Average Energi Not Supplied (AENS)

Indeks ini memberikan informasi tentang total energi yang tidak terkirim dalam satu tahun.

AENS $=\frac{\text { ENS }}{\sum \text { LP }}$

Dimana:

ENS : 42,1842 MWh/tahun

$\sum$ LP : 11764titik beban

AENS $=\frac{42,1842}{11764}$

$=0,00358 \mathrm{MWh} /$ pelanggan

\subsubsection{Hasil Simulasi pada ETAP}

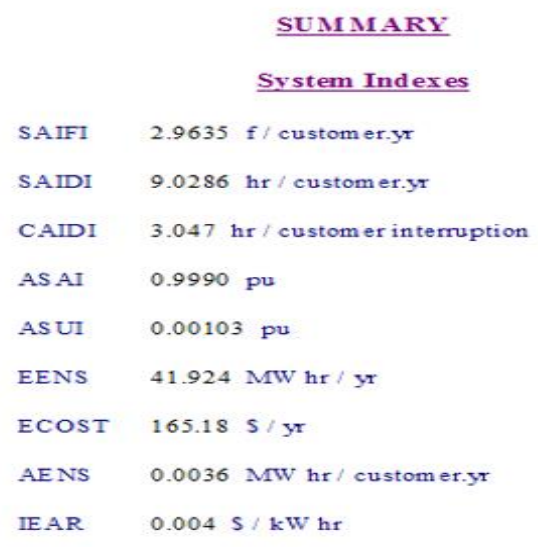




\section{Gambar 4.Indeks keandalan hasil simulasi}

Dari Gambar 4 dapat dilihat indeks keandalan penyulang MRA05 dimana nilai SAIFI sebesar 2,9635 gangguan/tahun, nilaia SAIDI sebesar 9,0286 jam/tahun, CAIDI senilai 3,047 jam/gangguan, nilai ENS sebesar 41,924 MWh/tahun, nilai AENS sebesar $0,0036 \mathrm{MWh} /$ pelanggan.

\subsection{Saat kondisi DG Terpasang}

Pada kondisi ini diasumsikan saat terjadi gangguan pada penyulang, maka PMT akan trip, sehinggasuplai beban ke titik beban akan putus, namun pada kondisi ini tidak semua titik beban pada penyulang padam.Titik beban yang menyala kembali ini disebabkan oleh adanya DG yang dapat beroperasi Islanded system , dengan DG beroperasi islanded system ini maka DG akan bertindak sebagai penyuplai beban pengganti untuk menghubungkan DG ke titik beban dan untuk memisahkan titik beban yang padam dengan titik beban yang akan disuplai oleh DG dengan skenario islanded system ini. DG tidak dapat menyuplai beban pada penyulang secara keseluruhan, DG hanya akan menyuplai beban sesuai dengan titik beban yang ada pada skenario islanded system. Berdasarkan single line diagram pada simulasi ETAP, skenario islanded system dapat dilihat pada tabel 8 dibawah ini

Tabel 8. Skenario islanded system

\begin{tabular}{|c|c|c|c|}
\hline $\begin{array}{c}\text { Islanded } \\
\text { System }\end{array}$ & DG & Skenario & $\begin{array}{l}\text { Titik beban yang } \\
\text { disuplai }\end{array}$ \\
\hline I & $\begin{array}{l}\text { PLTMH } \\
\text { Sigebang }\end{array}$ & $\begin{array}{l}\text { ABSW } \\
\text { MRA05.05 dan } \\
\text { ABSW } \\
\text { MRA05.061 } \\
\text { dalam kondisi } \\
\text { open }\end{array}$ & Load 1, Load 2, Load 3 \\
\hline II & $\begin{array}{l}\text { PLTMH } \\
\text { Kincang, } \\
\text { PLTMH } \\
\text { Adipasir, } \\
\text { PLTMH } \\
\text { Rakit }\end{array}$ & $\begin{array}{l}\text { LBS } \\
\text { MRA05.105.s7 } \\
1 \text { dan ABSW } \\
\text { MRA05.105.S1 } \\
\text { 49.b01 dalam } \\
\text { kondisi open }\end{array}$ & $\begin{array}{l}\text { Load 57, Load 58, Load } \\
\text { 59, Load 129, Load } \\
\text { 130, Load 60, Load } \\
\text { 131, Load 61, Load 62, } \\
\text { Load 63, Load 64, Load } \\
\text { 65, Load 66,Load 67, } \\
\text { Load 68, Load 69, Load } \\
\text { 70, Load 71, Load 72, } \\
\text { Load 73, Load 145, } \\
\text { Load 74, Load 75, Load } \\
\text { 76, Load } 77\end{array}$ \\
\hline
\end{tabular}

\section{a. System Average Interruption Frequency Index (SAIFI)}

Besarnya nilai SAIFI saat DG kondisi terpasang sama dengan besarnya nilai SAIFI saat kondisi DG tidak terpasang, hal ini dikarenakan pada penyulang ini, satu penyulang hanya terdapat satu PMT, sehingga dimanapun terjadi gangguan pada penyulang, maka PMT akan trip dan semua titik beban akan padam. Sehingga adanya DG tidak mempengaruhi nilai
SAIFI, oleh karena itu nilai SAIFI saat DG terpasang tetap sama dengan saat DG tidak terpasang, yaitu

SAIFI $=\frac{\sum \lambda_{i} N_{i}}{N_{i}}$

SAIFI $=2,96228$ gangguan $/$ tahun

\section{b. System Average Interruption Duration Index (SAIDI)}

Untuk dapat mencari besarnya nilai SAIDI maka terlebih dahulu mencari lama gangguan pada titik beban pada tabel 8 yang saat DG beroperasi islanded system. karena dengan DG beroperasi islanded system ini menyebabkan titik beban yang seharusnya padam ketika PMT trip menjadi menyala, maka lama gangguan untuk titik beban pada tabel 8 saat DG beroperasi islanded system saya asumsikan menjadi 0 jam/tahun. Sehingga lama gangguan (U) titik beban pada tabel 8 hanya dipengaruhi oleh lama gangguan antara PMT trip dengan DG mulai beroperasi islanded system. keadaan diantara PMT trip dan DG mulai beroperasi islanded system ini di asumsikan adalah waktu yang dibutuhkan untuk komponen switching ( ABSW atau LBS) bekerja untuk mengubungkan DG ke titik beban dan untuk memisahkan daerah yang masuk dalam skenario islanded system dengan daerah yang tidak.

Tabel 9. Rekapitulasi besarnya nilai lama gangguan pertahun pada titik- titik beban saat DG terpasang

\begin{tabular}{|c|l|c|c|c|}
\hline No. & \multicolumn{1}{|c|}{$\begin{array}{c}\text { Titik } \\
\text { Beban }\end{array}$} & \multicolumn{1}{c|}{$\begin{array}{c}\mathbf{U}_{\mathbf{i}} \\
\text { (h/year) }\end{array}$} & $\begin{array}{c}\mathbf{L}_{\mathbf{i}} \\
(\mathbf{K W})\end{array}$ & $\mathbf{~ N}$ \\
\hline 1 & Load-1 & 0,15 & 41,65 & 65 \\
2 & Load-2 & 0,15 & 41,65 & 47 \\
3 & Load-3 & 0,15 & 41,65 & 65 \\
4 & Load-4 & 2,46 & 41,65 & 141 \\
5 & Load-5 & 2,85 & 41,65 & 120 \\
$\ldots$. & $\ldots .$. & $\ldots .$. & $\ldots$. & $\ldots$. \\
144 & Load-143 & 15,00 & 20,825 & 65 \\
145 & Load-144 & 15,03 & 41,65 & 65 \\
\hline \multicolumn{4}{|c|}{ TOTAL } \\
\hline
\end{tabular}

Dari tabel 9 diatas dapat ditentukan indeks rata-rata durasi pemadaman yang dialami pelanggan dalam periode satu tahun (SAIDI) sebagai berikut.

SAIDI $=\frac{\sum \mathrm{U}_{\mathrm{i}} \mathrm{N}_{\mathrm{i}}}{\mathrm{N}_{\mathrm{i}}}$
SAIDI $=\frac{\sum((0,15 \times 65)+(0,15 \times 47)+. .+(15,03 \times 65))}{11764}$
SAIDI $=7,567 \mathrm{jam} /$ tahun

\section{c. Customer Average Interruption Durtion index(CAIDI)}


Indeks ini memberikan informasi lama waktu (durasi) rata-rata setiap pemadaman Indeks ini dirumuskan dengan

$$
\begin{aligned}
\text { CAIDI } & =\frac{\text { SAIDI }}{\text { SAIFI }}=\frac{7,567}{2,96228} \\
& =3,233 \text { jam } / \text { gangguan }
\end{aligned}
$$

\section{d. Energy Not Supplied (ENS)}

Indeks ini memberikan informasi tentang total energi yang tidak terkirim dalam satu tahun.

$$
\begin{aligned}
& \mathrm{ENS}=\sum L a(i) \cdot U i \\
& \mathrm{ENS}=\sum \begin{aligned}
41,65 \times 0,15+41,65 \times 0,15+\cdots+ \\
20,825 \times 15,00+41,65 \times 15,03
\end{aligned} \\
& \mathrm{ENS}=35115,78557 \mathrm{KWh} / \mathrm{tahun} \\
& \mathrm{ENS}=35,11578 \mathrm{MWh} / \mathrm{tahun}
\end{aligned}
$$

$$
\text { e. Average Energi Not Supplied (AENS) }
$$

Indeks ini memberikan informasi tentang total energi yang tidak terkirim ke pelanggan dalam satu tahun AENS $=\frac{\text { ENS }}{\sum \text { LP }}$

Dimana:

ENS : $35,11578 \mathrm{MWh} /$ tahun

$\sum$ LP : 11764titik beban

AENS $=\frac{35,11578}{11764}=0,0029 \mathrm{MWh} /$ pelanggan

\subsection{Perhitungan Data Real di Lapangan}

Untuk menghitung indeks SAIFI, SAIDI, CAIDI, berdasarkan pemadaman yang terjadi dilapangan maka harus diketahui durasi pemadaman dan frekuensi pemadaman selama tahun 2017 pada penyulang MRA05. Data tersebut dapat dilihat pada Tabel 10 berikut.

Tabel 10. Data pemadaman PMT pada penyulang MRA05

\begin{tabular}{|c|l|c|c|}
\hline No & \multicolumn{1}{|c|}{ Tanggal } & $\begin{array}{c}\text { Lama Padam } \\
\text { (jam) }\end{array}$ & $\begin{array}{c}\text { Pelanggan } \\
\text { padam }\end{array}$ \\
\hline 1 & 11 januari 2017 & 5,28 & 11764 \\
2 & 13 januari 2017 & 3,23 & 11764 \\
3 & 04 februari 2017 & 2,25 & 11764 \\
4 & 01 maret 2017 & 3,58 & 11764 \\
5 & 10 maret 2017 & 3,23 & 11764 \\
6 & 01 april 2017 & 4,17 & 11764 \\
7 & 16 april 2017 & 0,65 & 11764 \\
8 & 11 juli 2017 & 1,47 & 11764 \\
9 & 15 juli 2017 & 2,53 & 11764 \\
10 & 26 juli 2017 & 1,63 & 11764 \\
11 & 05 september 2017 & 0,80 & 11764 \\
12 & 19 oktober 2017 & 3,67 & 11764 \\
13 & 25 oktober 20177 & 1,25 & 11764 \\
14 & 19 novemebr 2017 & 1,10 & 11764 \\
15 & 26 desember 2017 & 3,38 & 11764 \\
\hline \multicolumn{3}{|c|}{ TOTAL } & 38,68 \\
\hline
\end{tabular}

a. System Average Interruption Frequency Index (SAIFI)

SAIFI

$$
\text { SAIFI }=\frac{\sum \lambda_{\mathrm{i}} \mathrm{N}_{\mathrm{i}}}{\mathrm{N}_{\mathrm{i}}}
$$

$$
\begin{gathered}
=\frac{\sum((1 \times 11764)+(1 \times 11764)+\cdots+(1 \times 11764))}{11764} \text { SAIFI } \\
=15 \text { gangguan } / \text { tahun }
\end{gathered}
$$

b. System Average Interruption Duration Index

\begin{tabular}{|c|c|c|c|}
\hline No & Tanggal & $\begin{array}{c}\text { Lama } \\
\text { Padam } \\
\text { (jam) }\end{array}$ & $\begin{array}{c}\text { Daya } \\
\text { tersambung } \\
(\mathrm{KW})\end{array}$ \\
\hline 1 & 11 januari 2017 & 5,28 & 5147,94 \\
\hline 2 & 13 januari 2017 & 3,23 & 5147,94 \\
\hline 3 & 04 februari 2017 & 2,25 & 5147,94 \\
\hline 4 & 01 maret 2017 & 3,58 & 5147,94 \\
\hline 5 & 10 maret 2017 & 3,23 & 5147,94 \\
\hline 6 & 01 april 2017 & 4,17 & 5147,94 \\
\hline 7 & 16 april 2017 & 0,65 & 5147,94 \\
\hline 8 & 11 juli 2017 & 1,47 & 5147,94 \\
\hline 9 & 15 juli 2017 & 2,53 & 5147,94 \\
\hline 10 & 26 juli 2017 & 1,63 & 5147,94 \\
\hline 11 & 05 september 2017 & 0,80 & 5147,94 \\
\hline 12 & 19 oktober 2017 & 3,67 & 5147,94 \\
\hline 13 & 25 oktober 2017 & 1,25 & 5147,94 \\
\hline 14 & 19 novemebr 2017 & 1,10 & 5147,94 \\
\hline 15 & 26 desember 2017 & 3,38 & 5147,94 \\
\hline \multicolumn{4}{|c|}{ TOTAL } \\
\hline
\end{tabular}
(SAIDI)

$$
\begin{aligned}
& \text { SAIDI }=\frac{\sum \mathrm{U}_{\mathrm{i}} \mathrm{N}_{\mathrm{i}}}{\mathrm{N}_{\mathrm{i}}} \\
& \text { SAIDI }=\frac{\sum((5,28 \times 1176}{}(2.20) \\
& 11764, 38 \times 11764)) \\
& \text { SAIDI }=38,68 \mathrm{jam} / \text { tahun }
\end{aligned}
$$

c. Customer Average Interruption Durtion index (CAIDI)

$$
\begin{aligned}
\text { CAIDI } & =\frac{\text { SAIDI }}{\text { SAIFI }}=\frac{38,68}{15} \\
& =2,5788 \mathrm{jam} / \text { gangguan }
\end{aligned}
$$

Untuk menghitung indeks ENS,dan AENS berdasarkan pemadaman yang terjadi dilapangan maka harus diketahui besarnya daya yang tidak terkirim selama tahun 2017

Tabel 11. Data pemadaman PMT pada penyulang MRA05

d. Energy Not Supplied (ENS)

$$
\begin{aligned}
& \mathrm{ENS}=\sum L a(i) \cdot U i \\
& \text { ENS }=\sum 5,28 x 5147,94+3,23 x 5147,94+\cdots+ \\
& 1,1 \times 5147,94+3,38 \times 5147,94
\end{aligned}
$$

ENS $=199139 \mathrm{KWh} /$ tahun 
ENS $=199,139 \mathrm{MWh} /$ tahun

e. Average Energi Not Supplied (AENS)

AENS $=\frac{\text { ENS }}{\sum \text { LP }}$

Dimana:

ENS : 199,139 MWh/tahun

$\sum$ LP : 145 pelanggan

AENS $=\frac{199,139}{145}=1,373 \mathrm{MWh} /$ pelanggan

\subsection{Perbandingan hasil perhitungan menggunakan metode RIA dengan simulasi ETAP}

\section{a. Kondisi DG tidak terpasang}

Tabel 12.Perbandingan hasil perhitungan menggunakan metode RIA dengan simulasi ETAP

\begin{tabular}{|l|c|c|}
\hline \multicolumn{1}{|c|}{ Indeks Keandalan } & RIA & ETAP \\
\hline SAIFI (gangguan/tahun) & 2,96228 & 2,9635 \\
SAIDI (jam/tahun) & 9,1185 & 9,0286 \\
\cline { 1 - 2 } CAIDI (jam/gangguan) & 3,078 & 3,047 \\
ENS (MWh/tahun) & 42,1842 & 41,924 \\
AENS (MWh/pelanggan) & 0,00358 & 0,0029 \\
\hline
\end{tabular}

Dari Tabel 12 diatas terlihat bahwa hasil perhitungan dengan menggunakan metode RIA sudah mendekati hasil simulasi pada ETAP, dimana nilai SAIFI menggunakan metode RIA sebesar 2,96228 gangguan/tahun sedangkan pada simulasi ETAP nilai SAIFI sebesar 2,9635 gangguan/tahun. Nilai SAIDI menggunakan metode RIA sebesar 9,1185 jam/tahun, sedangkan pada simulasi ETAP sebesar 9,0286 jam/tahun. Nilai CAIDI menggunakan metode RIA sebesar 3,078 jam/gangguan, sedangkan pada simulasi ETAP sebesar 3,047 jam/gangguan. Nilai ENS menggunakan metode RIA sebesar 42,1842 MWh/tahun, sedangkan pada simulasi ETAP sebesar 41,924 MWh/tahun. Nilai AENS menggunakan metode RIA sebesar 0,00358 MWh/pelanggan, sedangkan pada simulasi pada ETAP sebesar 0,0029 MWh/pelanggan.

\subsection{Perbandingan hasil perhitungan menggunakan metode RIA dan hasil simulasi saat DG tidak terpasang dengan perhitungan data real dilapangan}

Tabel 13. Perbandingan hasil perhitungan menggunakan metode RIA dan simulasi ETAP dengan data real di lapangan

\begin{tabular}{|l|c|c|c|}
\hline Indeks Keandalan & RIA & ETAP & $\begin{array}{c}\text { Data } \\
\text { Lapangan }\end{array}$ \\
\hline SAIFI \\
(gangguan/tahun) & 2,96228 & 2,9635 & 15 \\
SAIDI (jam/tahun) & 9,1185 & 9,0286 & 38,68 \\
CAIDI & 3,078 & 3,047 & 2,5788 \\
(jam/gangguan) & &
\end{tabular}

Copyright @ 2019 FT-UHAMKA. - All rights reserved DOI : 10.22236/teknoka.v\%vi\%i.4170

\begin{tabular}{|l|c|c|c|}
\hline $\begin{array}{l}\text { ENS } \\
\text { (MWh/tahun) }\end{array}$ & 42,1842 & 41,924 & 199,139 \\
$\begin{array}{l}\text { AENS } \\
\text { (MWh/pelanggan) }\end{array}$ & 0,00358 & 0,0029 & 1,373 \\
\hline
\end{tabular}

Dari Tabel 13 dapat dilihat bahwa indeks keandalan hasil perhitungan data di lapangan memiliki perbedaan dibandingkan indeks keandalan hasil perhitungan menggunakan metode RIA dan hasil simulasi ETAP. Dimana nilai SAIFI menggunakan metode RIA sebesar 2,96228 gangguan/tahun, simulasi ETAP sebesar 2,9635 gangguan/tahun, sedangkan perhitungan data lapangan sebesar 15 gangguan/tahun. Nilai SAIDI menggunakan metode RIA sebesar 9,1185 jam/tahun, pada simulasi ETAP sebesar 9,0286 jam/tahun, sedangkan perhitungan data lapangan sebesar 38,68 jam/tahun. Nilai CAIDI menggunakan metode RIA sebesar 3,078 jam/gangguan, pada simulasi ETAP sebesar 3,047 jam/gangguan, sedangkan perhitungan data lapangan sebesar 2,5788 jam/gangguan. Nilai ENS menggunakan metode RIA sebesar 42,1842 MWh/tahun, pada simulasi ETAP sebesar 41,924 MWh/tahun, sedangkan perhitungan data lapangan sebesar 199,139 MWh/tahun . Nilai AENS menggunakan metode RIA sebesar 0,00358 MWh/pelanggan, simulasi pada ETAP sebesar 41,924 MWh/pelanggan, sedangkan perhitungan data lapangan sebesar 1,373 MWh/pelanggan.

\subsection{Perbandingan perhitungan saat DG tidak terpasang dan terpasang.}

Tabel 14.Perbandingan hasil perhitungan saat DG tidak terpasang dan terpasang

\begin{tabular}{|l|c|c|}
\hline \multicolumn{1}{|c|}{ Indeks Keandalan } & $\begin{array}{c}\text { DG tidak } \\
\text { terpasang }\end{array}$ & $\begin{array}{c}\text { DG } \\
\text { terpasang }\end{array}$ \\
\hline SAIFI (gangguan/tahun) & 2,96228 & 2,96228 \\
SAIDI (jam/tahun) & 9,1185 & 7,567 \\
CAIDI (jam/gangguan) & 3,078 & 2,5546 \\
ENS (MWh/tahun) & 42,1842 & 35,11578 \\
AENS (MWh/pelanggan) & 0,00358 & 0,0029 \\
\hline
\end{tabular}

Dari tabel 14 diatas terlihat hasil simulasi indeks keandalan saat DG tidak terpasang dan terpasang. Dimana besarnya nilai SAIFI saat DG tidak terpasang sebesar 18,1156 gangguan/tahun, sedangkan saat DG terpasang sebesar 18,1156 gangguan/tahun, Nilai SAIDI saat DG tidak terpasang sebesar 58,5678 jam/tahun, saat DG terpasang sebesar 47,404 jam/tahun,. Nilai CAIDI saat DG tidak terpasang sebesar 3,233 jam/gangguan, saat DG terpasang sebesar 2,616 jam/gangguan,. Nilai ENS saat DG tidak terpasang sebesar 301,5035 MWh/tahun, saat DG terpasang sebesar 247,975 MWh/tahun. Nilai AENS saat DG tidak terpasang sebesar 2,0793 MWh/pelanggan, saat DG terpasang sebesar 1,710 MWh/tahun. Dari tabel 14 dapat disimpulkan bahwa dengan adanya DG yang terpasang dapat meningkatkan keandalan pada penyulang MRA05. Dapat dilihat dengan semakin kecilnya nilai indeks keandalan SAIDI, CAIDI, ENS dan AENS. Sedangkan untuk besarnya nilai SAIFI tidak mengalami perubahan saat DG tidak terpasang dan terpasang, hal ini 
dikarenakan pada penyulang hanya terdapat satu buah PMT, sehingga dimanapun terjadi gangguan pada penyulang maka PMT akan trip. Dengan demikian maka hasil perhitungan sudah sesuai dengan teori yang ada.

\subsection{Perbandingan SAIFI dan SAIDI penyulang MRA05 dengan SPLN 68-2 Tahun 1986}

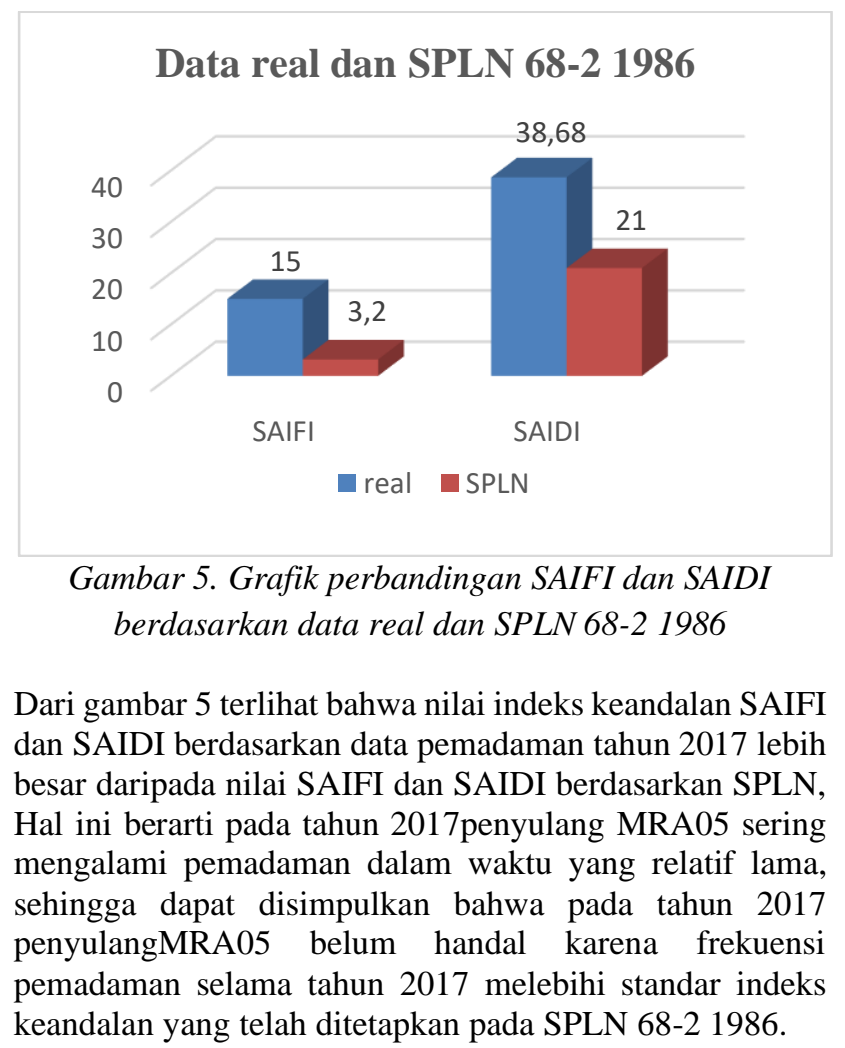

\section{SIMPULAN}

Berdasarkan hasil perhitungan dan analisis yang telah dilakukan pada saat kondisi DG tidak terpasang dengan menggunakan metode Reliability Index Assesment(RIA), besarnya indeks keandalan pada penyulang MRA05 adalah SAIFI sebesar 2,96228 gangguan/tahun, SAIDI sebesar 9,1185 jam/tahun, CAIDI sebesar 3,078 jam/pelanggan, ENS sebesar 42,1842 MWh/tahun, AENS sebesar 0,00358 MWh/pelanggan. Pada kondisi DG terpasang dengan menggunakan metode RIA, besarnya indeks keandalan pada penyulang MRA05 adalah SAIFI sebesar 2,9635 gangguan/tahun, SAIDI sebesar7,567 jam/tahun.

\section{KEPUSTAKAAN}

[1] Ifanda, dkk. "Kajian Outage management Sistem Kelistrikan".Serpong: Badan Pengkajian dan Penerapan teknologi (BPPT). 2014.

[2] Praditama, Fery. "Analisis Keandalan dan Nilai Ekonomis di Penyulang Pujon PT. PLN (Persero) Area Malang”. Universitas Brawijaya, 2012
[3] Aziz, Thariq Fathony, Penentuan Target Indeks keandalan, Drop Tegangan, dan Rugi Daya pada feeder SRLO7 GI srondol menggunakan ETAP 7.5.0, Tugas Akhir, Universitas Diponegoro, Semarang, 2015.

[4] Putro, A. P., Analisis Tegangan Jatuh Sistem Distribusi Listrik Kabupaten Pelalawan dengan Menggunakan ETAP 7.5.0., Skripsi, Universitas Diponegoro, Semarang, 2015.

[5] Tim Penyusun,Diklat Profesi Pengoperasian Jaringan dan Sambungan Tegangan Rendah, PT. PLN (Persero) Pusat Pendidikan dan Pelatihan, 2012.

[6] Chowdury, Ali A. dan Koval, Don O., Power Distribution System Reliability, John Wiley \& Sons Inc. Publication, New Jersey, 2009.

[7] SPLN 68-2:1986. Tingkat jaminan sistem tenaga listrik.

[8] Short, Thomas A., Electric Power Distribution Handbook Second Edition, CRC Press Taylor \& Francis Group, USA, 2014.

[9] Afriana, Elza, "Perbandingan Indeks Keandalan Sistem Distribusi pada Penyulang SELO3 dalam Keadaan Perfect switching dan Imperfect switching”, Tugas Akhir, Universitas Diponegoro, Semarang, 2017.

[10] Anggoro, D. C. "Analisa Pemanfaatan Limbah Cair Kelapa Sawit Sebagai Bahan Bakar Pembangkit Terdistribusi Untuk Mereduksi Rugi-Rugi Daya Pada Jaringan Distribusi Kabupaten Pelalawan", Skripsi, Universitas Diponegoro, Semarang, 2015..

[11] Grarehpetian, G.B and S. Mohammad Mousavi Agah. "Distributed Generation System Design, Operation, and Grid Integration"Cambridge, 2017.

[12] SPLN $59:$ 1985. Keandalan pada Sistem Distrbusi $20 \mathrm{kV}$ dan $6 \mathrm{kV}$ 